\title{
The Clinical and Demographic Characteristics of Our Cases with Primary Bone Tumors and Soft Tissue Tumors
}

\author{
Zeynep ORUC ${ }^{1}$, Muhammet A. KAPLAN ${ }^{1}$, Halis YERLIKAYA ${ }^{1}$, M. Ali CELIK ${ }^{2}$, Idris ORUC ${ }^{3}$, \\ Zuhat URAKCI $^{1}$, Mehmet KUCUKONER ${ }^{1}$, Abdurrahman ISIKDOGAN ${ }^{1}$
}

${ }^{1}$ Dicle University, Faculty of Medicine, Department of Medical Oncology

${ }^{2}$ Dicle University, Faculty of Medicine, Department of Internal Medicine

${ }^{3}$ Diyarbakır Training and Research Hospital, Internal Medicine, Diyarbakır, TURKEY

\begin{abstract}
The current study aimed to investigate the clinical and demographic characteristics of the patients with sarcoma who were treated and followed-up in Dicle University Medical Oncology Department. We retrospectively investigated the medical records of 547 patients who were diagnosed with sarcoma in the Dicle University School of Medicine, Department of Medical Oncology, between 2007 and 2015. When we considered the total number of patients (total 23,264) admitted to our center between 2007 and 2015 , the rate of our patients with sarcoma was found to be $2.3 \%$ of this total number. Primary bone tumor and soft tissue sarcoma were determined in 32\% ( $n=172)$ and 68\% ( $n=375)$ of the patients, respectively. The most frequent histological type was osteosarcoma. The age, location of the primary tumor, adjuvant chemotherapy, location of relapse (local, metastatic), history of smoking, and comorbid diseases showed statistically significant differences between two groups. The overall survival and progression-free survival also did not differ significantly between the primary bone tumors and soft tissue tumors $(p=0.65)$. The rate of our patients with sarcoma was $2.3 \%$ of the total number of patients (total 23,264 ) admitted to our center. This rate is higher than that in the literature.It is hard to interpret the results of the study, however it has been confirmed that the soft tissue sarcomas and primary bone tumors differ with regard to the age at diagnosis, location of tumor, location of relapse, prevalence of adjuvant chemotherapy and risk factors.
\end{abstract}

Keywords: Sarcoma, Bone tumor, Soft tissue tumor

ÖZET

Primer Kemik Ve Yumuşak Doku Tümörlü Olgularımızın Klinik Ve Demografik Özellikleri

Merkezimizde takip ve tedavi edilmiş olan sarkom hastalarının klinik ve demografik özelliklerini araştırmak amaçlanmıştır. Dicle Üniversitesi Tıp Fakültesi Tıbbi Onkoloji Bilim Dalında 2007-2015 yılları arasında sarkom tanısı alan 547 hastanın dosyaları retrospektif olarak incelendi. Sarkoma hastalarımızın sayısı,2007-2015 tarihleri arasında merkezimize başvuran tüm kanser hastalarınının sayısına(toplam: 23.264) oranlandığında,saptadığımız değer \%2.3 idi. Hastaların \%32'si(n:172) primer kemik tümörü \%68'i (n: 375) yumuşak doku sarkomu idi. En sık görülen histolojik tip, osteosarkom \%14.5 (n:79). Yaş ,primer tümör yerleşim yeri, adjuvan kemoterapi, nüks yeri (lokal, metastatik),sigara öyküsü ve komorbid hastalıklar gibi parametreler açısından her iki grup arasında istatistiksel olarak anlamlı farkllık saptandı. Yumuşak doku tümörleri ve primer kemik tümörleri arasında tüm survival ve progresyonsuz survival açısından anlamlı farklılık saptanmadı (p: 0.65). Sarkoma tanılı hastalarımız, merkezimize başvuran tüm hastaların \%2.3 idi. Bu oran literature verilerine göre daha yüksek bir değerdi. Sarkomların çok farklı histolojik subtipleri içermesi nedeniyle çalışma sonuçlarının yorumlanması güç olmakla birlikte yumuşak doku sarkomu ve primer kemik tümörleri arasında tanı yaşı,tümör yerleşim yeri, nüks yeri, adjuvan kemoterapi yaygınlı̆̆ı ve risk faktörleri açısından da farklııkların olduğu doğrulandı.

Anahtar Kelimeler: Sarkom, Kemik tümörü, Yumuşak doku tümörü 


\section{INTRODUCTION}

Sarcomas account for $1 \%$ of all cancers existing in adults. Sarcomas form a heterogeneous group of cancers with mesenchymal origin. Although they are rarely seen tumors, they include more than 70 different histological types. ${ }^{1}$ Despite their heterogeneities and biological variabilities, they have been evaluated and treated as the same diseases until recently. The biological variabilities of sarcomas have been recently defined. ${ }^{2}$ Many of these subtypes may exist in any age, and they are not limited to a specific localization of the body. In general, sarcomas are investigated in two groups, as the malignant bone tumors and the soft tissue sarcomas. ${ }^{3}$ The soft tissue sarcomas commonly originate from the muscle, joint, adipose tissue, nerves, deep dermal tissues, and blood vessels, and they are categorized according to their histopathological similarities of the normal tissue. The primary bone tumors have been grouped by the World Health Organization as the osteogenic tumors, cartilaginous tumors, Ewing's sarcoma-PNET group, and tumors of the hematologic system. ${ }^{4}$

When compared to the other cancers, sarcomas are present more frequently in young adults and adolescents. They are rarely existing cancers with poor prognoses. ${ }^{5}$ There is not available clarified data related to the real incidences of sarcomas in Turkey. However, according to the data of the Turkish Association for Cancer Research and Control reported in 2009, the incidences of soft tissue tumors and primary bone tumors are 1.5/100,000 and $0.8 / 100.000$, respectively in the females, and $2.4 / 100,000$ and $1.2 / 100.000$, respectively in the males. ${ }^{6}$ The present study aimed to contribute to the knowledge related to sarcoma incidence in Turkey, the distribution of its histological subtypes, the differences between genders, and risk factors.

\section{MATERIALS AND METHODS}

We retrospectively evaluated the medical records of 547 patients who were diagnosed with sarcoma at the Dicle University School of Medicine Medical Oncology Department, between 2007 and 2015. The medical records were investigated regarding the age, gender, risk factors (smoking, family history of cancer), comorbid diseases, location of the primary tumor, histological type, size of tumor, stage at diagnosis, grade of tumor, presence of relapse, location of relapse, and therapeutic modalities (surgery, adjuvant therapy, and palliative chemotherapy). The overall survival was defined as the duration from the date of diagnosis to the date of the last control or death. The progressionfree survival was defined as the duration from the date of diagnosis to the time of recurrence or progression of disease or to death.

The patients with sarcoma were separated as two groups; primary bone tumors(PBT) and soft tissue sarcomas (STS) and the groups were compared regarding the clinical parameters. Ewing's sarcoma, chondrosarcoma, and osteosarcoma were included in the group with primary bone tumors, using the World Health Organization's classification. The location of the primary tumor was grouped as follows: head-neck, upper extremity, lower extremity, retroperitoneal/intraabdominal, visceral organ, thorax, and flat bones (vertebra, pelvis).

Statistical analysis was performed using the SPSS 18.0 statistical software. Data were analyzed using the chi-square test, log rank test and MannWhitney U-test. Survival was evaluated using the Kaplan-Meyer method. p value less than 0.05 was accepted as statistically significant.

\section{RESULTS}

The study included a total of 547 patients. Of these, $41.9 \%(n=229)$ were female and $58.1 \%(n=318)$ were male. Of the 547 patients, $32 \%(n=172)$ had primary bone tumors(PBT) and $68 \%(n=375)$ had soft tissue sarcomas (STS). Characteristics of the patients are presented in Table 1. Gender did not differ significantly between the two groups (in PBT, female $40.3 \%(n=71)$, male $59.7 \%(n=105)$; in STS, female $42.6 \%(n=158)$, male $57.4 \%(n=$ 213), $\mathrm{p}=0.619)$. The mean ages were 42 years (range: 11-95 years) in all cases with sarcoma, 22 years (range: 11-71 years) in cases with PBT, and 49 years (range: 13-95 years) in cases with STS $(\mathrm{p}<0.001)$. The most common histological type was osteosarcoma $14.5 \%(n=79)$ (Table 2). The most common histological type in females was osteosarcoma $15.9 \%(n=36)$. In males, the most common histological type was Ewing's sarcoma $15.4 \%(n=48)$. The most common histological type of PBT was osteosarcoma (45\%). The most com- 
International Journal of Hematology and Oncology

\begin{tabular}{|c|c|c|c|c|}
\hline Patient characteristics & $\begin{array}{l}\text { Number of patients } \\
\% \text { (n: } 547)\end{array}$ & $\begin{array}{l}\text { Soft tissue sarcomas } \\
\text { (STS) } 68 \% \text { (n: } 375 \text { ) }\end{array}$ & $\begin{array}{l}\text { Primary bone tumors } \\
\text { (PBT) } 32 \% \text { (n: 172) }\end{array}$ & $p$ value \\
\hline Median Age & $42(11-95)$ & $49(13-95)$ & $22(11-71)$ & $<0.001$ \\
\hline \multicolumn{5}{|l|}{ Gender } \\
\hline Female & $41.9 \%(229)$ & $42.6 \%(158)$ & $40.3 \%(71)$ & \multirow[t]{2}{*}{0.619} \\
\hline Male & $58.1 \%(318)$ & $57.4 \%(213)$ & $59.7 \%(105)$ & \\
\hline \multicolumn{5}{|c|}{ Location of primary tumor (n:514) } \\
\hline Head/neck & $7 \%(36)$ & $8 \%(27)$ & $5.1 \%(9)$ & \multirow[t]{7}{*}{$<0.001$} \\
\hline Upper extremity & $9.4 \%(48)$ & $8.6 \%(29)$ & $10.9 \%(19)$ & \\
\hline Lower extremity & $36.3 \%(186)$ & $26.6 \%(90)$ & $54.9 \%(96)$ & \\
\hline Retroper/intraab & $11.3 \%(58)$ & $16.3 \%(55)$ & $1.7 \%(3)$ & \\
\hline Visceral organ & $18.3 \%(94)$ & $26.6 \%(90)$ & $2.3 \%(4)$ & \\
\hline Thorax & $7.8 \%(40)$ & $7.1 \%(24)$ & $9.1 \%(16)$ & \\
\hline Flat bones (vertebra, pelvis) & $9.9 \%(51)$ & $6.8 \%(23)$ & $16 \%(28)$ & \\
\hline \multicolumn{5}{|l|}{ Tumor size (n: 193) } \\
\hline$<5$ & $24.4 \%(47)$ & $27.2 \%(37)$ & $17.5 \%(10)$ & \multirow[t]{3}{*}{0.084} \\
\hline $5-10$ & $31.6 \%(61)$ & $33.8 \%(46)$ & $26.3 \%(15)$ & \\
\hline$>10$ & $44 \%(85)$ & $39 \%(53)$ & $56.2 \%(32)$ & \\
\hline \multicolumn{5}{|l|}{ Grade (n: 140 ) } \\
\hline 1 & $29.3 \%(41)$ & $32.2 \%(37)$ & $16 \%(4)$ & \multirow[t]{3}{*}{0.198} \\
\hline 2 & $22.1 \%(31)$ & $20 \%(23)$ & $32 \%(8)$ & \\
\hline 3 & $48.6 \%(68)$ & $47.8 \%(55)$ & $52 \%(13)$ & \\
\hline \multicolumn{5}{|l|}{ Surgery (n: 460) } \\
\hline Yes & $79.1 \%(364)$ & $79.9 \%(238)$ & $77.8 \%(126)$ & \multirow[t]{2}{*}{0.599} \\
\hline No & $20.9 \%(96)$ & $20.1 \%(60)$ & $22.2 \%(36)$ & \\
\hline \multicolumn{5}{|c|}{ Metastatic disease at diagnosis (n: 484) } \\
\hline Yes & $28.1 \%(136)$ & $27.3 \%(87)$ & $29.7 \%(49)$ & \multirow[t]{2}{*}{0.574} \\
\hline No & $71.9 \%(348)$ & $72.7 \%(232)$ & $70.3 \%(116)$ & \\
\hline \multicolumn{5}{|l|}{ Adjuvant $\mathrm{CT}^{\star}(\mathrm{n}: 371)$} \\
\hline Yes & $56.6 \%(210)$ & $44.9 \%(109)$ & $78.9 \%(101)$ & \multirow[t]{2}{*}{$<0.001$} \\
\hline No & $43.4 \%(161)$ & $55.1 \%(134)$ & $21.1 \%(27)$ & \\
\hline \multicolumn{5}{|l|}{ Adjuvant $\mathrm{RT}^{\star}$ (n:400) } \\
\hline Yes & $38.2 \%(153)$ & $39 \%(104)$ & $36.8 \%(49)$ & \multirow[t]{2}{*}{0.683} \\
\hline No & $61.8 \%(247)$ & $61 \%(163)$ & $63.2 \%(84)$ & \\
\hline \multicolumn{5}{|l|}{ Recurrence (n: 268) } \\
\hline Yes & $61.6 \%(165)$ & $58.8 \%(104)$ & $67 \%(61)$ & \multirow[t]{2}{*}{0.187} \\
\hline No & $38.4 \%(103)$ & $41.2 \%(73)$ & $33 \%(30)$ & \\
\hline \multicolumn{5}{|l|}{ Site of recurrence (n:168) } \\
\hline Local & $38.7 \%(65)$ & $46.7 \%(49)$ & $25.4 \%(16)$ & \multirow[t]{2}{*}{0.006} \\
\hline Distant & $61.3 \%(103)$ & $53.3 \%(56)$ & $74.6 \%(47)$ & \\
\hline \multicolumn{5}{|l|}{ History of smoking } \\
\hline Present & $25.5 \%(139)$ & $29.5 \%(109)$ & $17 \%(30)$ & \multirow[t]{2}{*}{$<0.001$} \\
\hline Absent & $74.5 \%(408)$ & $70.5 \%(262)$ & $83 \%(146)$ & \\
\hline \multicolumn{5}{|l|}{ Family history of cancer } \\
\hline Present & $8.8 \%(47)$ & $6.9 \%(25)$ & $12.5 \%(22)$ & 0.097 \\
\hline Absent & $71.2 \%(500)$ & $93.1 \%(341)$ & $87.5 \%(159)$ & \\
\hline Comorbid disease & & & & \\
\hline Present & $17 \%(92)$ & 20.9 \% (76) & $9.1 \%(16)$ & 0.003 \\
\hline Absent & $83 \%(455)$ & $79.1 \%(295)$ & $90.9 \%(160)$ & \\
\hline
\end{tabular}

UHOD Number: 3 Volume: 26 Year: 2016 
International Journal of Hematology and Oncology

\begin{tabular}{|c|c|c|c|}
\hline Histological types & $\begin{array}{l}\text { Number of patients } \\
100 \% \text { (n: } 547 \text { ) }\end{array}$ & & $\begin{array}{l}\text { Number of } \\
\text { patients } \\
100 \% \text { (n: } 547 \text { ) }\end{array}$ \\
\hline Malign Mesenchymal Tumor (not specified) & $11.1 \%(60)$ & Soft tissue sarcomas & $\% 68(375)$ \\
\hline Osteosarcoma & $14.5 \%(79)$ & $\begin{array}{l}\text { Gastrointestinal stromal } \\
\text { tumor }\end{array}$ & $20 \%(75)$ \\
\hline Ewing's Sarcoma & $13.5 \%(74)$ & $\begin{array}{l}\text { Malign mesenchymal } \\
\text { tumor \% (not specified) }\end{array}$ & $16 \%(60)$ \\
\hline Synovial sarcoma & $3.3 \%(19)$ & Liposarcoma & $10 \%(38)$ \\
\hline Kaposi's Sarcoma & $4.6 \%(26)$ & Pleomorphic sarcoma & $8 \%(30)$ \\
\hline Liposarcoma & $7.1 \%(38)$ & Kaposi sarcoma & $6 \%(22)$ \\
\hline Rhabdomyosarcoma & $2 \%(11)$ & The Others & $\% 40(150)$ \\
\hline Pleomorphic sarcoma (malignant fibrous histiocytoma) & $5.8 \%(31)$ & Primary bone tumors & $\% 32(172)$ \\
\hline Dermatofibrosarcoma protuberans & $2.8 \%(15)$ & osteosarcoma & $45 \%(78)$ \\
\hline Peripheral nerve sheath tumors & $2.4 \%(13)$ & Ewing's sarcoma & $43 \%(74)$ \\
\hline Chondrosarcoma & $3.3 \%(19)$ & chondrosarcoma & $12 \%(20)$ \\
\hline Alveolar sarcoma & $0.2 \%(1)$ & & \\
\hline Fibrosarcoma & $3.7 \%(21)$ & & \\
\hline Angiosarcoma & $0.6 \%(3)$ & & \\
\hline Chordoma & $0.9 \%(5)$ & & \\
\hline Carcinosarcoma & $1.1 \%(6)$ & & \\
\hline Giant cell bone tumor & $1.1 \%(6)$ & & \\
\hline Fibromatosis & $1.1 \%(6)$ & & \\
\hline Gastrointestinal stromal tumor & $13.5 \%(74)$ & & \\
\hline Uterine Leiomyosarcoma & $3.7 \%(21)$ & & \\
\hline Non uterine Leiomyosarcoma & $2.2 \%(12)$ & & \\
\hline Hemangiopericytoma/endothelioma & $0.7 \%(4)$ & & \\
\hline Clear Cell Sarcoma & $0.6 \%(3)$ & & \\
\hline
\end{tabular}

mon histological type of STS was gastrointestinal stromal tumor (20\%) (Table 2). History of smoking was present in $25.5 \%(\mathrm{n}=139)$ of the patients (in $29.5 \%(n=109)$ of the cases with STS; in $17 \%$ $(n=30)$ of the cases with PBT )and most of these patients $(78.4 \%)$ had STS. The two groups differed statistically significantly $(\mathrm{p}<0.001)$. Family history of cancer was present in $8.8 \%(n=47)$ of the cases (in $12.5 \%(n=22)$ of the cases with PBT and in $6.9 \%(n=25)$ of the cases with STS). The difference between the two groups was close to the level of statistical significance, regarding the family history of cancer $(p=0.097)$. History of comorbid diseases was present in $17 \%(n=92)$ of the patients (in $9.1 \%(n=16))$ of the PBT and in $20.9 \%(n=$ 76) of the STS). A statistically significant differ- ence was determined between the two groups $(\mathrm{p}=$ 0.003) (Table 1).

In the 514 patients whose tumor locations were reported, the location of primary tumors in sarcomas was lower extremity $(36.3 \%, \mathrm{n}=186)($ table 1$)$. The location of primary tumors differed statistically significantly, as expected, between the PBT and STS groups $(\mathrm{p}<0.001)$. The lower extremity $(26.6 \%)$ and visceral organ $(26.6 \%)$ were most common sites of tumor location in the STS.In the 193 patients whose tumor sizes were reported, the values were as follows; tumor size $<5 \mathrm{~cm}$ in $24.4 \%$ $(\mathrm{n}=47), 5 \mathrm{~cm}-10 \mathrm{~cm}$ in $31.6 \%(\mathrm{n}=61)$ and tumor size $>10 \mathrm{~cm}$ in $44 \%(\mathrm{n}=85)$ of the cases. The values regarding the size of tumor in PBT and STS are presented in Table 1 . The difference between the 
two groups was close to the level of statistical significance, regarding the size of tumor $(\mathrm{p}=0.084)$. The grades of tumors were reported in 140 patients and they were distributed as follows: $29.3 \%(\mathrm{n}=$ 41) grade $1,22.1 \%(n=31)$ grade 2 and $48.6 \%(n=$ 68 ) grade 3 . The values regarding the grade of tumor in PBT and STS are presented in Table 1. The grade of tumor did not differ significantly between the PBT and STS groups $(\mathrm{p}=0.198)$. A total of 484 patients were evaluated for metastatic disease at diagnosis and the rate of metastatic state at diagnosis was $28.1 \%(n=136)$. Of the 136 patients who had metastasis at diagnosis, 36\% $(n=49)$ were cases with PBT and $64 \%(n=87)$ were cases with STS. The rates of metastatic disease in the PBT and STS were $29.7 \%$ and $27.3 \%$, respectively. The PBT and STS groups did not differ statistically significantly regarding the metastatic disease at diagnosis $(\mathrm{p}=$ 0.574 ). The presence of relapse was evaluated in a total of 268 patients. in the course of a median 38.7-month follow-up, relapse existed in $61.6 \%$ $(n=165)$ of the cases (in \%58.8 $(n=104)$ of the STS and in \%67 $(n=61)$ of the cases with PBT). The rate of relapse did not differ significantly between the groups with PBT and STS ( $=0.187)$. The site of relapse was reported in 168 patients; of these, $38.7 \%(n=65)$ had local relapse, and $61.3 \%$ $(n=103)$ had distant recurrence. The rates of local relapse in the PBT and STS were $25.4 \%$ and $46.7 \%$, respectively. The rates of distant recurrence in the PBT and STS were $74.6 \%$ and $53.3 \%$, respectively. A statistically significant difference was determined between the two groups regarding the site of recurrence $(\mathrm{p}=0.006)$ (Table 1).

The patients were evaluated regarding the therapeutic modalities and the state of being suitable for operation was reported in 460 cases. Of these cases, $79.1 \%(\mathrm{n}=364)$ underwent surgery and $79.1 \%(\mathrm{n}=$ 364) were found to be suitable for surgical treatment. The rates of being suitable for surgery were found to be $77.8 \%(n=126)$ in the cases with PBT and $79.9 \%(n=238)$ in the cases with STS; this difference was not statistically significant $(\mathrm{p}=0.599)$. Of the 371 patients who were evaluated for the administration of adjuvant chemotherapy,56.6\% ( $\mathrm{n}=$ 210) received adjuvant chemotherapy and $43.4 \%$ $(n=161)$ did not receive this treatment.The rates of administration of adjuvant chemotherapy in the groups with PBT and STS were 78.9\% $(\mathrm{n}=101)$ and $44.9 \%(n=109)$, respectively; the difference between groups was statistically significant $(\mathrm{p}<$ 0.001).Of the 400 patients who were evaluated for the administration of adjuvant radiotherapy, $38.2 \%$ $(\mathrm{n}=153)$ were cases undergoing adjuvant RT and $61.8 \%(n=247)$ were cases not undergoing this treatment. The rates of cases receiving adjuvant radiotherapy were $36.8 \%(n=49)$ in the PBT and $39 \%$ $(n=104)$ in the STS; the difference between groups was not significant $(\mathrm{p}=0.683)$.

In the period of median 38.7-month follow-up, $61.6 \%(n=165)$ had relapse. The durations of progression-free survival were 27 months $(95 \% \mathrm{CI}$ : 19.6-34.5) in the cases with PBT and 27.6 months (95\% CI: 23.1-32.1) in the cases with STS; this difference was not statistically significant $(\mathrm{p}=0.65)$. The durations of overall survival were 35.1 months (95\% CI: 25.6-44.6) in the cases with primary bone tumors, and 40.1 months (95\% CI: 24-56.1) in the cases with STS; this difference was not statistically significant $(\mathrm{p}=0.46)$.

\section{DISCUSSION}

Sarcomas are tumors that are studied to a lesser extent compared to other types of cancer. Their rare existence and the presence of a wide variety of different subtypes make it difficult to evaluate the sarcomas in studies. There is a wide range of epidemiological studies related to sarcomas. An epidemiological study of sarcomas performed in 2008 using the data of SEER determined that the soft tissue sarcomas account for about $87 \%$ of all cases of sarcoma, and the malignant bone tumors account for $13 \%$ of them. The most common malignant bone tumors are osteosarcomas and chondrosarcomas and they constitute more than half $(51.2 \%)$ of all cases with malignant bone tumors. The soft tissue sarcomas include fibrosarcomas and peripheral nerve tumors (7\%), Kaposi's sarcoma (9\%) and unspecified soft tissue sarcomas (16.8\%). ${ }^{7}$

Studies have demonstrated that geographical differences exist in the incidence of sarcomas all over the world. ${ }^{8}$ Because of the existence of these geographical differences, it is considered that both genetic and environmental factors possibly contribute to the etiology of sarcoma. Mastrangelo et al. conducted a prospective, multi-center study for two years in three European regions, in order 
to detect new cases of sarcoma; in this study, only 1558 individuals were diagnosed with sarcoma, in a population of 26.000 .000 . Of these patients, 968 were diagnosed with soft tissue sarcoma and 590 were diagnosed with visceral sarcoma. The four major histological subtypes accounted for $60 \%$ of the cases, which were determined as follows: gastrointestinal stromal tumor, uterine and non-uterine leiomyosarcoma, liposarcoma and unclassified sarcomas. ${ }^{9}$

There is not sufficient data indicating the real incidences and diagnostic distributions of bone and soft tissue tumors in Turkey. In an epidemiological study of Yücetürk et al. conducted in the Aegean region and including 5658 patients with bone and soft tissue tumors, it was determined that $39.7 \%$ of the bone and soft tissue tumors are malignant mesenchymal tumors, $50.2 \%$ of which are the primary bone tumors and $49.8 \%$ of which are soft tissue tumors. Types and frequencies of bone tumors were determined to be as follows: $33.6 \%$ osteosarcoma, $25.5 \%$ Ewing's sarcoma, $19.4 \%$ chondrosarcoma and $17.6 \%$ hematological malignancies. The rates of malignancies included in the soft tissue sarcomas were as follows: $24.5 \%$ pleomorphic sarcomas, $16.4 \%$ liposarcomas, $13 \%$ synovial sarcoma, and $8.8 \%$ undifferentiated sarcomas. ${ }^{10}$ In this study, the patients particularly suspected of skeletal system tumors (primary or metastatic) were evaluated; therefore it is not possible to obtain knowledge about some sarcomas characterized with the involvement of visceral organs (GIST, uterine leiomyosarcomas). The distribution of the bone and soft tissue tumors present in the extremities was investigated in the region of Van by Kösem et al.; in this study, malignant bone and soft tissue neoplasms related to the extremities were present at a rate of $3.5 \%$ in males and at a rate of $4.9 \%$ in females, among the all cases with cancer. ${ }^{11}$

The present study included 547 patients with malignant bone and soft tissue tumors who were followed-up and treated at the Dicle University Medical Oncology center, which is a regional hospital; it therefore reflects demographic characteristics of the southeast region. These results were compared with those in the literature. Of the 547 patients evaluated in our study, $32 \%(n=172)$ were the cases with primary bone tumor(PBT) and $68 \%(\mathrm{n}=$
375) were the cases with soft tissue sarcoma (STS). Osteosarcoma (45\%), Ewing's sarcoma (43\%) and chondrosarcoma (12\%) were the most common histological types of the PBT. Gastrointestinal stromal tumor (20\%), malignant mesenchymal tumor (not specified) (16\%), liposarcoma (10\%), pleomorphic sarcoma (8\%) and Kaposi's sarcoma (6\%) were determined to be the most common histological types existing in the STS (Table 2). Our results related to the rates of PBT are close to those in the literature; however, the rates of the STS include some differences from those in the literature. According to the SEER and NCHS statistics, the mean age for the existence of STS is 58 years, and it is 40 years for the existence of malign bone tumors. ${ }^{12}$ ). In our study, the mean ages in the cases with PBT and STS were found to be 22 years (range: 11-71 years) and 49 years (range: 13-95 years), respectively. This result confirms the knowledge that PBT exist in younger ages, compared with the STS. In our study; gender, the size of tumor, the grade of tumor, therapeutic modalities like surgery and adjuvant RT, metastatic disease at diagnosis, presence of recurrence and family history of cancer did not differ significantly between the two groups.

In our study, the most common site of location of the primary tumor was the lower extremity (36.3\%) and the visceral organ was in the second order in frequency $(18.3 \%)$. The site of location differed significantly between the PBT and STS groups, as expected $(\mathrm{p}<0.001)$. Location in the lower extremity was determined at higher rates in the PBT; however, the lower extremity and visceral organ was the most common sites of location in the STS, also, which is in accordance with the literature. ${ }^{9}$ The lungs are the most frequent sites of metastasis in sarcomas. In our study, the rates of local relapse in PBT and STS were $25.4 \%$ and $46.7 \%$, respectively; the rates of distant recurrence in PBT and STS were $74.6 \%$ and $53.3 \%$, respectively $(\mathrm{p}=0.006)$. The rate of local relapse was higher in STS and the rate of distant recurrence was higher in PBT (Table 2). This may be attributed to the many different histological types of STS in different grades and to the existence of more aggressive sarcomas in the group with PBT. In our study, the rates of administration of adjuvant chemotherapy in PBT and STS were $78.9 \%$ and $44.9 \%$, respectively; this difference between groups was significant $(\mathrm{p}<0.001)$. 
This result was attributed to the following factors: adjuvant chemotherapy is not a standard application in the STS and it is applied in the presence of various high-risk factors (such as high grade and a large tumor size) and adjuvant chemotherapy is a more common application in patients with malignant bone tumors, compared to cases with STS.

The factors leading to sarcoma have not yet been completely clarified. Professional and chemical exposures have been shown to be additional risk factors for all subtypes of sarcoma; however, there is not a consensus related to these risk factors and the development of sarcoma. ${ }^{13,14}$ There is a very limited number of studies investigating the effect of smoking on the development of sarcoma. In a case-controlled study including 228 cases and 1610 control subjects, it was determined that chewing tobacco increases the risk of soft tissue sarcoma (OR: $1.895 \%$ CI 1.1, 2.9). ${ }^{15}$ However, in another study including 93 cases and 721 control subjects and investigating the relationship between the use of alcohol/cigarettes and soft tissue sarcoma, no significant relationships were determined between these factors..$^{16}$ In our study, the rate of smoking was found to be higher in the cases with STS (78.4\%), compared to the patients with PBT $(\mathrm{p}<0.0001)$. It was concluded that the existence of STS at more advanced ages compared to PBT might have contributed to this result. We evaluated the family history of cancer in our study, and determined that $8.8 \%(n=47)$ of the patients had a family history of cancer $12.5 \%(n=22)$ in PBT and 6.9\% $(n=25)$ in STS. This difference between the groups was not statistically significant; however, the rate of family history of cancer was higher in cases with PBT $(p=0.097)$. The small number of cases might have contributed to the statistical non-significance. When the comorbid states were evaluated, the rate of comorbid diseases was higher in cases with STS $(20.9 \%)(p=0.003)$. This difference may be due to the presence of STS at more advanced ages. In our study, the durations of overall survival and progression-free survival did not show statistically significant differences between the groups with PBT and STS. The presence of PBT and STS in various different histological subtypes make it difficult to evaluate the results related to survival.
When we considered the total number of cancer patients (total number: 23.264) who were enrolled our center between the years of 2007 and 2015, the percentage of cases with sarcoma of this total number $(2.3 \%)$ was higher than that in the literature. Sarcomas are more frequent in young adults and adolescents when compared with the other cancers and Southeast Anatolia is characterized by a large young population; these are among the factors that have contributed to this result.

Our study is important, since it is the single study in Turkey that has so far evaluated the distribution of sarcoma subtypes, with their clinical characteristics and therapeutic modalities. The retrospective nature of the study and the unavailability of complete data in some patient records are the limitations to our study.

In conclusion, the most common soft tissue tumor in our center is the gastrointestinal stromal tumor, and osteosarcoma is the most common primary bone tumor. Sarcomas include a wide variety of different histological subtypes, and it is therefore not easy to interpret the study results; however, we confirmed in this study that the soft tissue sarcomas and primary bone tumors also differ with regard to the age at diagnosis, site of tumor location, site of relapse, prevalence of adjuvant chemotherapy and risk factors.

\section{REFERENCES}

1. Reichardt P. Soft tissue saromas, a look into the future: different treatments for different subtypes. Future Oncol 10: (8 Suppl) 19-27, 2014.

2. Verweij J, Baker LH. Future treatment of soft tissue sarcomas will be driven by histological subtype and molecular aberrations. Eur J Cancer 46: 863-868, 2010.

3. Lahat G, Lazar A, Lev D. Sarcoma epidemiology and etiology:potential environmental and genetic factors.Surg Clin North Am 88: 451-481, 2008.

4. A Snapshot of Sarcoma. National Cancer Institute. Sept 2010.http//www.cancer.gov/aboutnci/servingpeople/cancer-statistics/snapshots B

5. Burningham Z, Hashibe M, Spector L, Schiffman J. The Epidemiology of Sarcoma. Clinical Sarcoma Res 2: 14, 2012.

6. TR. Ministry of Health, Directorate of Cancer Control Administration: Evaluation of Cancer Reports (2009). http://www. iccp-portal.org/sites/default/files/plans/TurkeyNATIONAL_ CANCER_PROGRAM2-1.pdf (Access Date :01/10/2015) 
International Journal of Hematology and Oncology

7. Surveillance, Epidemology and End Results (SEER) Program (www.seer.cancer.gov) SEER ${ }^{\star}$ Stat Database: IncidenceSEER 9 Regs Research Data. http://seer.cancer.gov/ csr/1975_2009/ (Access Date 04/09/2015).

8. In Cancer Incidence in Five Continents, Volume IX. IARC Scientific Publications No.160. Edited by Curado MP, Edwards B. Shin HR, Storm H. Ferlay J, HeanueM, Boyle P. Lyon: IARC; 2007. https://www.iarc.fr/en/publications/pdfs-online/ epi/sp160/Cl5vol9-A.pdf (Access Date:01/10/2015)

9. Mastrangelo G, Coindre JM, Ducimetriere F, et al. Incidence of soft tissue sarcoma and beyond:a population-based prospective study in 3 European regions.Cancer 118: 53395348, 2012.

10. Yücetürk G, Sabah D, Keçeci B, et al. Prevalence of bone and soft tissue tumors. Acta Orthop Traumatol Turc 45: 135-43, 2011.

11. Kösem M, Bayram I. Distribution and Evaluation of Bone and Soft Tissue Tumors in Extremities in the Region of Van. Medical Journal of Van 8: 93-96, 2001.

12. Howlader N, Noone AM, Krapcho M, et al. SEER Cancer Statistics Review, 1975-2008. National Cancer Instute. http:// seer.cancer.gov/archive/csr/1975_2011/_ (Access Date 04/09/2015).

13. Pukkala E, Martinsen JI, Lynge E, et al.Occupation and cancer -follow up of 15 million people in five Nordic countries. Acta Oncol 48: 646-790, 2009.

14. Wingren G, Frendrikson M, Brage HN, Nordenskjöld B, Axelson O. Soft tissue sarcoma and occupational exposures. Cancer 66: 806-811, 1990.

15. Zahm SH, Blair A, Holmes FF, et al. A case-control study of soft tissue sarcoma. Am J Epidemiol 130: 665-674, 1989.

16. Serraino D, Franceschi S, Talamini R, La Vecchia C. Non-occupational risk factors for adult soft tissue sarcoma in northern Italy. Cancer Causes Control 2: 157-164, 1991.

\section{Correspondence}

Dr. Zeynep ORUC

Dicle Üniversitesi Tip Fakültesi

Tibbi Onkoloji Anabilim Dali

20280 Sur, DIYARBAKIR / TURKEY

Tel: (+90-0506) 3714896

mail: zeynep44oruc@hotmail.com 